FAG Journal of Health

\title{
A rare occurrence of esophageal spinocellular carcinoma in a young adult
}

\section{Rara ocorrência de carcinoma espinocelular de esôfago em paciente jovem}

Vinícius Antonio Peron ${ }^{1 *}$, Carlos Floriano de Morais ${ }^{1}$, Ana Cláudia Paiva Alegre Maller ${ }^{2}$,

Mauro Willemann Bonatto ${ }^{3}$

${ }^{1}$ Curso de Medicina. Centro Universitário da Fundação Assis Gurgacz.

${ }^{2}$ Doutora, docente do curso de Medicina. Centro Universitário da Fundação Assis Gurgacz

${ }^{3}$ Médico Gastroenterologista. Gastroclínica Cascavel.

\section{ARTICLE INFO}

Article history:

Received 16 September 2020

Revised 17 October 2020

Accepted 21 November 2020

Available online 20 December 2020

Blind reviews

\section{Keywords:}

Carcinoma

Squamous cell carcinoma of head and

neck

Esophageal neoplasms

Oncology

\begin{abstract}
Esophageal squamous cell carcinoma is a relatively uncommon neoplasm that affects advanced age groups. Here we report a case of an invasive esophageal squamous cell carcinoma that affected a 17-year-old male patient with some evidence showing that the early stages of neoplastic development were throughout childhood. No risks factors were identified and the patient had an excellent long-term outcome.
\end{abstract}

\footnotetext{
Palavras-chave:

Carcinoma

Carcinoma de células escamosas da cabeça e pescoço

Neoplasias esofágicas

Oncologia
}

\begin{abstract}
RESUMO
$O$ carcinoma de células escamosas é uma neoplasia relativamente incomum que afeta pessoas de faixa etária avançada. Neste relato de caso reportamos um carcinoma espinocelular invasivo em um paciente masculino de 17 anos, com possível início do desenvolvimento neoplásico ainda na infância. Não foram identificados fatores de risco e o paciente teve um excelente resultado a longo prazo.
\end{abstract}

\footnotetext{
* Corresponding author at:

vini_aperon@hotmail.com, https://orcid.org/ 0000-0003-3496-0969
} 


\section{Introduction}

Esophageal squamous cell carcinoma (ESCC) is an uncommon malignant neoplasm that often affects people between the ages of 50 and 60 years (QUEIROGA \& PERNANBUCO, 2006). Here, however, we present a rare case of a 17-year-old male patient who was affected by this disease. This provide us with a warning in order to consider this disease among the youngest and also not to delay diagnosis that can be otherwise lethal. In spite of the fact that the epidemiological data and risk factors seem to be essential to base a clinical diagnosis, some diseases may occur out of the ordinary and unexpectedly, especially in the oncologic field.

Thus, even though ESCC is a neoplasm that associated with elderly patients with known risk factors, it should never be excluded as a clinical suspicion in patients who have not shown such characteristics.

This research is in accordance to CNS resolution 466/12 of CONEP and it has been approved by the Research Ethics Committee Involving Human Beings at Centro Universitário da Fundação Assis Gurcagz, registered under CAAE number 00863618.1.0000.5219.

\section{Case presentation}

F.R.M., now 36-year-old white male patient who currently lives in the town of Naviraí-MS. The patient was firstly diagnosed with infiltrative ESCC in 1999 at the age of 17. He denied HPV lesions anywhere as well as having tilosys/hyperkeratosis. He was the only one to have such lesion in his family. He was not a tobacco smoker, though he claims to be a passive one and occasionally have being drinking small quantities of alcohol. He has also denied having allergies and mentioned treatment with synthroid for hypothyroidism. No records were obtained of drinking of "chimarrão", a traditional Brazilian yerba mate tea.

His family medical records have shown one case of a paternal uncle who was diagnosed with stomach cancer at the age of 55. His father had a renal cancer treated with nephrectomy at the age of 63 and after developed liver metastases that led to his death after a risky operation to remove the tumor.

The disease started he was 17 years-old with the patient complaining of dysphagia. While undergoing an upper digestive endoscopy, a necrotic and vegetative lesion was diagnosed in the upper esophagus, $1.5 \mathrm{~cm}$ to $2 \mathrm{~cm}$ in size, located $17 \mathrm{~cm}$ of the mouth (Figure 1), staged as cancer of the esophagus cT2cN0 (TNM 2017). There was a partial obstruction in the upper part of the esophagus which prevented the endoscope to pass through. A biopsy was performed and an infiltrative squamous cell carcinoma was diagnosed (Figure 2 and 3). No metastases were detected. In situ hybridization for HPV was negative (HPV types 6, 11, 16, 18, 31, 33, 35, 39, $4)$.

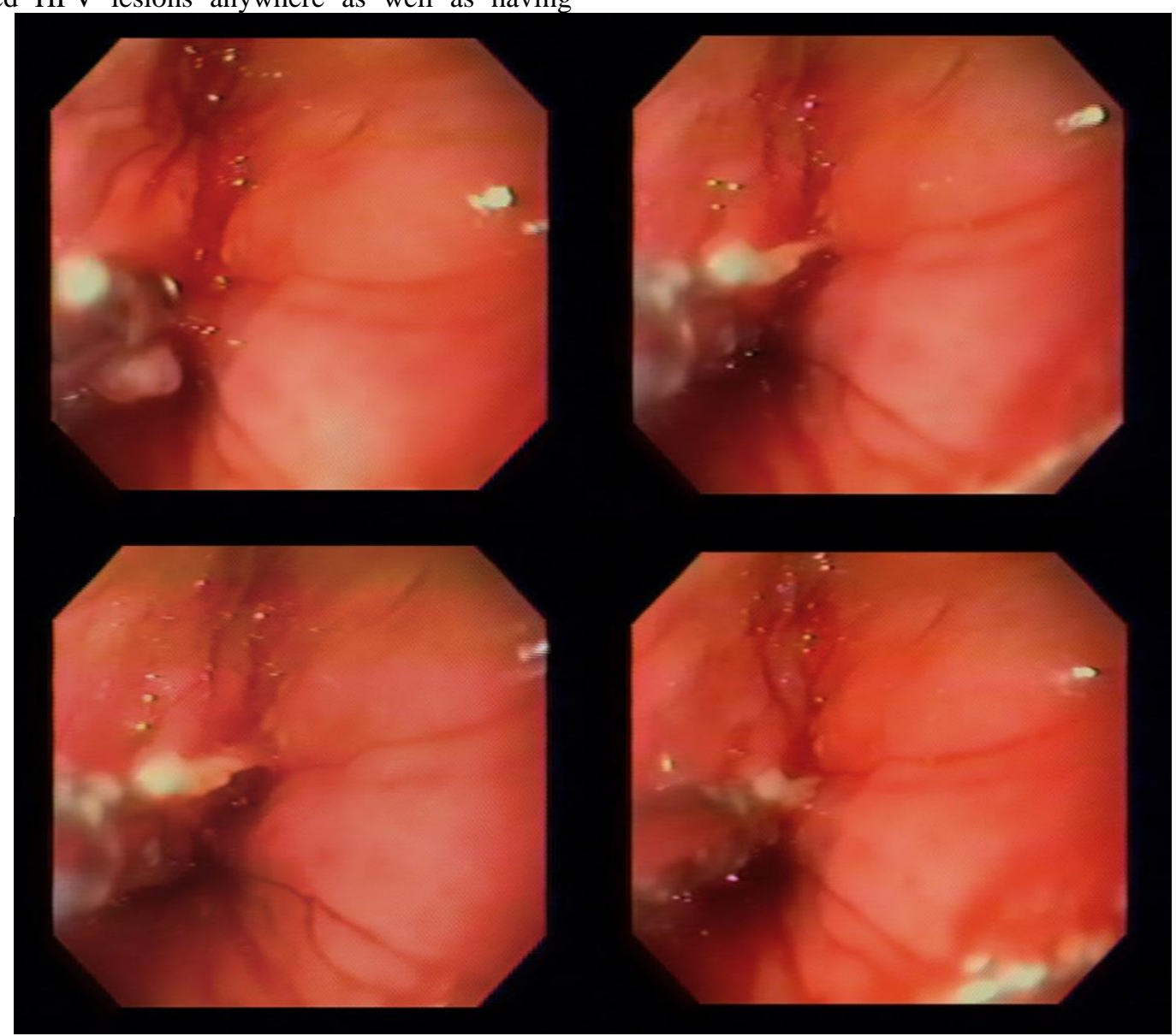

Figure 1 - Upper digestive endoscopy revealing the neoplasia of the esophagus. 


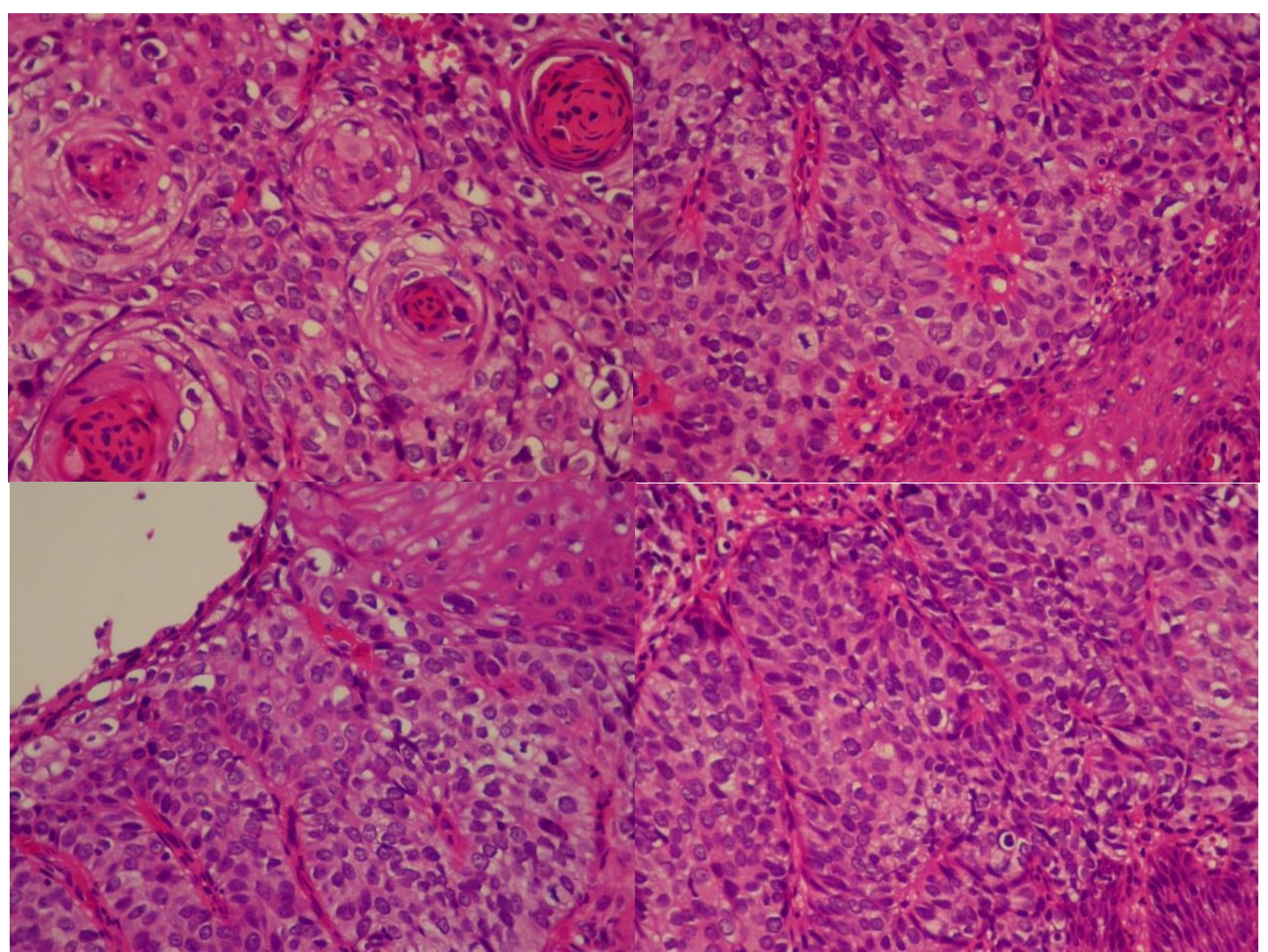

Figure 2 - Biopsy showing infiltrative epidermoid carcinoma, moderately differentiated.

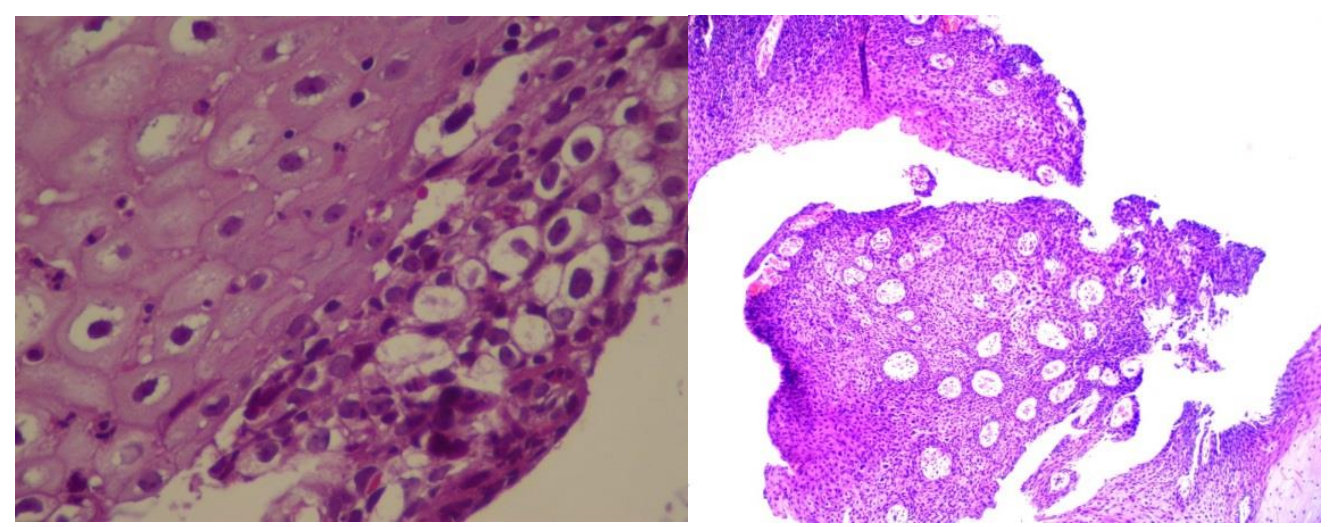

Figure 3 - Left, biopsy with areas of normal esophageal squamous epithelium (upper part of the photo) and foci of neoplasia in the lower part. There is cytoplasmic vacuolation reminiscent of coilocytes. To the right areas of squamous epithelium within normality.

The patient started treatment shortly after turning 18 years of age, and went through a five-day chemotherapy treatment followed by a two-week radiotherapy, from Monday to Friday. This course of treatment lasted three months and afterwards the patient had one week of recovery due to immune system related infection. He eventually presented actinic stenosis and was therefore submitted to serial dilations. Once the treatment had ended, an oncologist provided adequate follow-up care to the patient for a period of 5 years (2001 to 2005) to watch for recurrence. Several esophageal biopsies confirmed absence of neoplasia.

In 2005 the patient was diagnosed as having Zenker's diverticulum from which he was treated and made a full recovery. Later, in 2015, the patient was again reported with proximal esophageal stenosis, which was dilated. Biopsies at that time had revealed inespecific chronic esophagitis only on a single occasion without neoplastic cells.
In 2016, when the patient was eating food rapidly he suffered a chocking incident. Endoscopy showed only a slight scar retraction without stenosis again without evidence of residual ESCC. The patient had to be submitted do endoscopic procedures during a 18-year period as follow-up care for the stenosis. At the moment the patient refers only symptoms related do esophageal stenosis, which have required routine examination and dilation procedures.

\section{Discussion}

ESCC is a rare and often lethal entity, which commonly affects male patients over 50 years of age especially in their 60s, particularly black men. In addition, this malignancy may be associated with low socioeconomic status (Queiroga and Pernambuco, 2006). In contrast, our study presents an ESCC in a 17 years-old, caucasian patient. 
The estimated number of new ESCC cases in Brazil in 2018 is 10,790 , from which 8,240 were males. Thus, esophageal cancer represents $3.8 \%$ of the cases in the country and it is the sixth most common type of male cancer. The rates, according to some Brazilian states, have shown that there are 1,080 cases in Paraná state, where the diagnosis of the present case was done, with 860 of them occurring in men. On the other hand, in Mato Grosso do Sul, the home state of our patient, there were 170 new cases in total for the year 2018 (INCA, 2018).

The proportion between the genders is 3,3 men for each woman, in Brazil. The peak in age groups is between 50 and 60 years of age (Queiroga and Pernambuco, 2006). The mortality rate in southern Brazil is 14.3 for the men and 4.2 for the women per 100,000 inhabitants. The earlier the ESCC diagnosis is made, the better is the prognosis with $95 \%$ survival rates within a five-year-period (ARANTES et al, 2012, page 534).

Most of these cancers are related to well-known risk factors, such as the consumption of alcohol and tobacco smoking, whether chewed or inhaled. Smoking alone increases the chance of ESCC 2 to 4 times and the relative risk increases proportionally to the amount of tobacco or alcohol used. The alcohol content in special is directly related to the development of the disease. Whiskey, for instance, represents a higher risk factor than beer (QUEIROGA AND PERNAMBUCO, 2006). The chronic consumption of both alcohol and tobacco by the patient has been denied in the case reported. The major risk factor for ESCC is the environment, followed by alcohol (no matter the amount consumed) and the intake of nitrogen compounds (ZAKKO et al, 2017).

However, there have been other factors, such as the consumption of junk food and beverages, canned vegetables (with nitrogen compounds), infectious agents (human papilloma virus), socioeconomic factors (malnutrition), celiac sprue, Plummer-Vinson or Paterson- Kelly syndromes, deficiencies of riboflavin, vitamins A, C and E, zinc and molybdenum.

Furthermore, tylosis, a rare autosomal dominant disorder and rare genetic syndrome, is also linked as risk factor. In this condition the individual risk for developing ESCC is 95\% (QUEIROGA AND PERNAMBUCO, 2006). In the present case the patient has never reported such type of lesions. Also, HPV infection has been denied by the patient and no suspected risky habits nor the factors above mentioned have been found at any stage of his life.

The most common symptoms of ESCC are progressive dysphagia and obstruction, which may evolve and be slowly progressive. This may lead to an altered oral intake of food from solid to increasingly liquid. Along with these symptoms, there may retrosternal discomfort, foreign body sensation, slight odynophagia, epigastralgia, blood loss, anorexia, nausea and unintended weight loss (QUEIROGA AND PERNAMBUCO, 2006).

Esophagoscopy has been regarded as the best method for diagnosis along with biopsy. ESCC may present itself as an advanced disease as a vegetative, ulcerated or infiltrating lesion. On the contrary, in its early stages it be identified as a superficial and generally flat, erosive or slightly elevated lesion. A 3\% Lugol's solution has been used to better identify the tumor and to guide the biopsy. In addition, ultrasonography may aid in determining the extent of tumor invasion as well as in the biopsy of any suspicious lymph nodes. Computed tomography and magnetic resonance imaging are complementary tools for tumor staging (VIEIRA et al, 2002).

It has been noticed that one of the greatest difficulties faced in Brazil as well as in Western countries is to promote early diagnosis in asymptomatic patients who may also display minimal endoscopic alterations. This has been shown to be the most appropriate method to perform as well as an effective and curative treatment. Furthermore, upper GI endoscopy with chromoendoscopy has been highly recommended as it may provide the most effective treatment scenario, though for screening programs it would be considered to have high costs in order to benefit a whole population. Therefore, such programs would only be targeted to the population who are at a higher risk (ARANTES et al, 2012).

It has been observed that in areas with a high incidence of ESCC rates, the figures have reached 30 or more cases per 100,000 person-year, which has eventually justified the mass application of screening procedures on these groups. This has improved the early detection of ESCC and its medical management with endoscopic resection strategy without surgery in a high proportion of patients (ARNAL, ARENAS AND ARBELOA, 2015).

There are two types of therapy for ESCC: a palliative treatment that requires exclusively chemotherapy and/or radiotherapy as well as the use of endoscopic prostheses; secondly, a curative intent treatment with radical surgical resection plus chemotherapy and/or neo-adjuvant radiotherapy (TERCIOTI Jr et al, 2009). The criteria for indications of endoscopic resection include in-depth involvement restricted to layers M1 and M2 (epithelium and lamina propria), a three-centimeter maximal longitudinal dimension and a three-quarter inferior lateral circumference with a maximum of four lesions (ARANTES et al, 2012).

Other current endoscopic therapies are: resection techniques (mucosectomy and endoscopic submucosal dissection, ESD) and ablation techniques. However, the latter ones do not allow histopathological analysis of the excised lesion, which makes it impossible to define whether such technique has been curative or not. Therefore, ablative methods are not indicated for esophageal ESCC (ARANTES et al, 2012).

ESD is an issue in Asia and it is considered to be the method of choice for early ESCC. Anyway, it not possible to conclude whether or not ESD will be feasible to be applied for the treatment of large-scale superficial ESCC in Western centers (ARANTES et al., 2012, p.541).

Surgical healing strategy includes either transthoracic, transhiatal or minimally invasive esophagectomy, which may or not require regional lymphadenectomy (AJANI et al, 2015).

Despite the recent progress, ESCC has continuously shown poor prognosis due to late diagnosis of an advanced disease. Nonetheless, one of the treatment modalities which has been introduced by many medical centers is a course of chemoradiotherapy followed by surgical interventions. The aim at first was to reduce local tumor volume and to eradicate occult micrometastases before resection in order to provide an improvement in survival (TERCIOTI Jr et al, 2009).

New approaches may involve use of immunotherapy combined with other treatments. Additionally, further studies have found that the combination of CTLA-4 and 
PD-1 blockers may activate different inhibitory pathways in order to improve antitumor response. The outcomes of such studies have been satisfactory and they are listed as follows: combination therapy with mogamulizumab (KW-0761) and nivolumab (ONO-4538/BMS-936558) in subjects with advanced solid tumors, including esophageal cancer (NCT02476123) and Phase I study of pre-operative combination therapy with mogamulizumab (anti-CCR4) and nivolumab (anti-PD-1) in patients with solid tumor (UMIN000021480). Other new approaches are under development which can potentially help the patients such as therapeutic peptide vaccines, oncolytic viruses and therapy with adoptive T cells. The complex biology and variety of tumor evasion strategies indicates that combination strategies are very important (KOJIMA, DOI, 2017).

In conclusion, although ESCC is usually mainly observed in older adults, healthcare professionals should be aware that young patients may also be affected as in the patient presented here. The sooner this malignant neoplasm is detected, the better chance for patient survival.

\section{Acknowledgement}

Teacher Eduardo Miguel Prata Madureira

Josiane Antonio Schuarz

Jorides Zoratto Neto

Paulo Víctor de Oliveira Macedo

Angélica Cristina Milan Marese

Edmund Bergson Sabka

Teacher Leandra Fumagalli

\section{Conflict of interest}

The authors declare that there is no conflict of interest.

\section{References}

AJANI JA, D'AMICO TA, ALMHANNA K, et al. Esophageal and Esophagogastric Junction Cancers. National Comprehensive Cancer Network (NCCN) Clinical Practice Guidelines in Oncology. Version 3.2015. Disponível em: https://pubmed.ncbi.nlm.nih.gov/31319389/

ARANTES V, PIÑEROS EAF, YOSHIMURA K, TOYONAGA T. Avanços na abordagem do carcinoma precoce de esôfago. Rev. Col. Bras. Cir.; 39(6): 534-543. 2012. Disponível em: https://www.scielo.br/pdf/rcbc/v39n6/15.pdf

ARNAL MJD, ARENAS AF, ARBELOA AL. Esophageal cancer: Risk factors, screening and endoscopic treatment in Western and Eastern countries. World J Gastroenterol. 21(26): 79337943. 2015. Disponível em: https://pubmed.ncbi.nlm.nih.gov/26185366/

INCA. Instituto Nacional de Câncer [homepage na internet]. Rio de Janeiro: INCA; Estimativa 2018 [citado em 22 Junho 2018]. Disponível em: http://www.inca.gov.br/estimativa/2018/

KOJIMA T, DOI T. Immunotherapy for Esophageal Squamous Cell Carcinoma. Curr Oncol Rep. 19: 33. 2017. Disponível em: https://pubmed.ncbi.nlm.nih.gov/28361224/

QUEIROGA RC, PERNAMBUCO AP. Câncer de esôfago: epidemiologia, diagnóstico e tratamento. Rev Bra Can. 52(2): 173-178. 2006. Disponível em: https://rbc.inca.gov.br/site/arquivos/n_52/v02/pdf/revisao3.pd $\underline{\mathrm{f}}$

TERCIOTI JR, V.; LOPES, L. R.; COELHO NETO, J. S.; ANDREOLLO, N. A. Aspectos atuais da terapêutica neoadjuvante no carcinoma epidermóide do esôfago. Revisão da literatura. ABCD Arq Bras Cir Dig. 22(1):33-40. 2009. Disponível em: https://www.scielo.br/scielo.php?script=sci_arttext\&pid=S01 02-67202009000100008\&lng=en\&nrm=iso
VIEIRA OM, CHAVES CP, MANSO JEF, EULÁLIO JMR. Clínica Cirúrgica: fundamentos teóricos e práticos. São Paulo: Atheneu; 2002. p. 193-8.

ZAKKO L, LUTZKE L, WANG KK. Screening and Preventive Strategies in Esophagogastric Cancer. Surg Oncol Clin N Am. 26(2): 163-178. 2017. Disponível em: https://www.ncbi.nlm.nih.gov/pmc/articles/PMC5554862/ 